\title{
The Influence of a Water Absorbing Geocomposite on Soil Water Retention and Soil Matric Potential
}

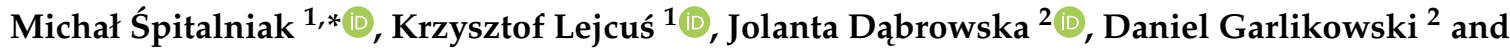 \\ Adam Bogacz ${ }^{3}$ \\ 1 Institute of Environmental Engineering, Wrocław University of Environmental and Life Sciences, \\ 50-363 Wroclaw, Poland \\ 2 Institute of Building Engineering, Wrocław University of Environmental and Life Sciences, \\ 50-363 Wroclaw, Poland \\ 3 Institute of Soil Sciences and Environmental Protection, Wrocław University of Environmental and Life \\ Sciences, 50-357 Wroclaw, Poland \\ * Correspondence: michal.spitalniak@upwr.edu.pl; Tel.: +48-71-320-5541
}

Received: 7 July 2019; Accepted: 18 August 2019; Published: 20 August 2019

\begin{abstract}
Climate change induces droughts that are becoming more intensive and more frequent than ever before. Most of the available forecast tools predict a further significant increase in the risk of drought, which indicates the need to prepare solutions to mitigate its effects. Growing water scarcity is now one of the world's leading challenges. In agriculture and environmental engineering, in order to increase soil water retention, soil additives are used. In this study, the influence of a newly developed water absorbing geocomposite (WAG) on soil water retention and soil matric potential was analyzed. WAG is a special element made from geotextile which is wrapped around a synthetic skeleton with a superabsorbent polymer placed inside. To describe WAG's influence on soil water retention and soil matric potential, coarse sand, loamy sand, and sandy loam soils were used. WAG in the form of a mat was used in the study as a treatment. Three kinds of samples were prepared for every soil type. Control samples and samples with WAG treatment placed at depths of $10 \mathrm{~cm}$ and $20 \mathrm{~cm}$ were examined in a test container of $105 \times 70 \times 50 \mathrm{~cm}$ dimensions. The samples had been watered and drained, and afterwards, the soil surface was heated by lamps of $1100 \mathrm{~W}$ total power constantly for $72 \mathrm{~h}$. Soil matric potential was measured by Irrometer field tensiometers at three depths. Soil moisture content was recorded at six depths: of 5, 9, 15, 19, 25, and $30 \mathrm{~cm}$ under the top of the soil surface with time-domain reflectometry (TDR) measurement devices. The values of soil moisture content and soil matric potential were collected in one-minute steps, and analyzed in 24-h-long time steps: 24, 48, and $72 \mathrm{~h}$. The samples with the WAG treatment lost more water than the control samples. Similarly, lower soil matric potential was noted in the samples with the WAG than in the control samples. However, after taking into account the water retained in the WAG, it appeared that the samples with the WAG had more water easily available for plants than the control samples. It was found that the mechanism of a capillary barrier affected higher water loss from soil layers above those where the WAG had been placed. The obtained results of water loss depend on the soil type used in the profile.
\end{abstract}

Keywords: water; water absorbing geocomposite; water soil retention; soil additives; geosynthetics; soil matric potential; superabsorbent polymers; water scarcity

\section{Introduction}

The impact of climate change on the environment, including people's lives, is noticeable [1-4]. More and more frequent problems with access to water and droughts are influencing agriculture and 
the safety of civil earth constructions [5-8]. This indicates the need to prepare solutions to mitigate the effects of the changes and to avoid unnecessary risk $[9,10]$. In the case of civil earth constructions like embankments, earth dams, or road slopes, it might be more complicated. Grass covers or shrubs, used for bioengineering slope stabilization, are exposed upon water scarcity [11,12]. Poorly maintained grass may affect surface erosion and shallow landslides, or even cause the destruction of the whole construction $[13,14]$. An insufficient water content in superficial soil layers leads to stability issues during wind erosion [15]. A conserved grass cover can delay the damage of the construction when overtopping occurs on a dike. It has been proven that grass and shrub roots act as a kind of natural surface reinforcement and have a role in construction stabilization [7,16-21]. The main agent for root development is the access to water [22-24]. Grass and shrubs can increase the safety factor for slopes up to $20 \%[16,25,26]$. To protect the construction from threatening atmospheric anomalies, mostly drought-resistant plant species are used, and also technical materials like geosynthetics or soil amendments [27]. An incorrect application of geosynthetics at the superficial layer of the slope might increase the drought stress of plants and further induce surface erosion $[27,28]$. However, that does not solve the problem of water scarcity. Drought-resistant plant species, especially grass covers, are less resistant than one would expect. Additionally, not every soil amendment is suitable for use in environmental engineering, on slopes, and for earth constructions. Applying a superabsorbent polymer to the soil by a mixing method can be dangerous because it reduces the soil shear strength [29].

In agriculture, one of the basic problems is similar-to ensure water resources necessary for plants' growth. Nowadays, water is seen as a supply whose cost is an important, still increasing part of the final product price. The direction of climate changes underlines a problem of water scarcity all over the world. Analyses point out that it is going to be difficult to feed future human generations without sustained agriculture [3]. Therefore, the significant development of a wide range of soil amendments and smart water systems cannot be surprising. Water dose is calculated according to a specific plant's needs and the soil water capacity. The technique of deficit irrigation or partial root-zone drying is also practiced for water use efficiency [30,31]. Soil amendments provide a different approach to the problem. Their objective is to retain water in the soil to be used by plants under drought stress conditions. Most soil conditioners are of an organic origin. Clay minerals like zeolite, kaolinite, or attapulgite are used in order to retain water and to prevent drainage or run off caused by gravity [32-37]. Investigations show that the application of mineral amendments for crop production allows water usage to be reduced. However, in the last decade, a few critical studies about their possible harmfulness for soil and the environment were published [38-40].

Superabsorbent polymers are a special kind of soil water retainer, also called hydrogels. These synthetic substances are three-dimensional cross-linked polymers. They might be used as fertilizer carriers and be biodegradable [41-45]. However, their main ability is water absorption [46-49]. One gram of dry mass can absorb up to $1000 \mathrm{~g}$ of distilled water [34,50]. This advantage makes superabsorbent polymers more useful and effective in water retention than mineral soil amendments. Unfortunately, that advantage might not be as significant as it sounds. Superabsorbent polymers are often applied in a saturated form to the soil by direct mixing or injecting [51]. This common mode of application is affected by the soil load. Therefore, the water absorbency of superabsorbent polymers is limited by their swelling ability. Some researchers that focus only on mixing methods claim that a superabsorbent polymer can be used for up to 6 months and then its efficiency significantly reduces [52]. Studies confirm that hydrogels are useful and suitable for growing media, especially for sandy soils $[49,51,53,54]$. Nevertheless, in agriculture or dryland restoration, the usage of a mix of watering methods is proposed: water irrigation—mineral soil amendment—superabsorbent polymer [55-58]. Regarding the mixing method of superabsorbent polymers, it might have some disadvantages resulting from swelling behavior. A superabsorbent polymer under swelling expands in volume and at the same time pushes the air out from soil pores. Most of the plant roots require at least $10 \%$ of the soil volume to be aerated [59]. On the other hand, there are studies confirming that mixed superabsorbents after desaturation affect the soil lowering bulk density and increase its porosity [60]. 
Lately, research about the swelling behavior of superabsorbent polymers under different soil loads has been conducted. The results have shown that the amount of water absorbed by a superabsorbent polymer depends on soil loads. For instance, water absorption decreased from $338.5 \mathrm{~g} \cdot \mathrm{g}^{-1}$ (control sample without load) to barely $19.3 \mathrm{~g} \cdot \mathrm{g}^{-1}$ under the load of a $30 \mathrm{~cm}$ thick soil layer of $1.3 \mathrm{~g} \cdot \mathrm{cm}^{-3} \mathrm{bulk}$ density [61].

Plant and soil water relations represent an interesting area which engages scientists all over the world aiming at a better understanding of the rhizosphere [62]. Water relations can be described in many ways, and one of them is soil moisture content (soil water content) and soil matric potential. Soil matric potential appears in unsaturated soil when the water present in the soil is under tension $[59,63,64]$. That tension in some range might be measured by field tensiometers, which are widely used in agriculture and wherever the information when plants should be irrigated and for how long to secure an optimal water plant status is needed. Depending only on information about soil moisture content might not be sufficient. Beside the soil moisture content, every plant species has got different root suction abilities. Equilibrium of the water relation in soils is difficult to achieve. Evapotranspiration, drainage, or transpiration creates a dynamic environment for every plant. The objective of irrigation systems and soil additives is to slow down those processes in order to minimize possible drought stress exerted on plants [59]. Water deficit is one of the factors triggering plant stress, especially in connection with nitrogen availability $[65,66]$. Drought stress affected plants might display slower growth, reduced biomass production, and in the worst scenario even a wilting process [67-69].

Considering all of the above, a new type of soil water retainer has been developed, called a water absorbing geocomposite (WAG). WAG is a special element built from nonwoven geotextile which is wrapped around a synthetic skeleton. A superabsorbent polymer is placed inside WAG [67]. Most plants are able to take up $95 \%$ of the water retained within the superabsorbent polymer [61]. Thanks to the synthetic skeleton, the superabsorbent polymer has space for swelling processes, which are essential for all types of superabsorbent polymers used in soil for agricultural and environmental engineering purposes [70]. That swelling process repeats itself when the superabsorbent desaturates and saturates again [71]. WAG in the form of a line and point has proven its ability to be used in agriculture, as well as in environmental engineering [72-75]. Studies have confirmed that the roots could overgrow the WAG and draw water from it. WAG contributes to the development of aboveground and underground parts of plants [76,77]. In addition, it supports plant development in degraded areas and difficult habitat conditions $[73,78]$. Regarding possible temperature changes induced by climate change, it might be a cost-effective water saving system for agriculture and civil engineering soil structures where there is a need. However, it has not yet been analyzed how the moisture content and soil matric potential change in the soil where WAG is used. It is important to understand how WAG interacts with different types of soils. In this article, the results of research on the influence of WAG (in the form of a mat) on soil moisture content and soil matric potential are presented. Moreover, literature lacks information on geosynthetics operating under heating conditions. Such knowledge would be valuable for establishing more detailed conditions of the WAG usage. Upgrading WAG might have an important positive influence on crop production and earth construction safety in the near future.

\section{Materials and Methods}

\subsection{Used Soil Material}

In order to describe the influence of WAG on soil water retention and soil matric potential, three types of soil were used: coarse sand, loamy sand, and sandy loam. Soils were collected at the Swojec Agricultural Experimental Station located in Wrocław, Lower Silesia, Poland ( $51^{\circ} 06^{\prime} 53^{\prime \prime} \mathrm{N}$, $17^{\circ} 08^{\prime} 27^{\prime \prime}$ E) and Research-Development Station of Vegetables and Ornamental Plants in Psary, Lower Silesia, Poland $\left(51^{\circ} 11^{\prime} 29^{\prime \prime} \mathrm{N}, 17^{\circ} 02^{\prime} 04^{\prime \prime} \mathrm{E}\right)$, both belonging to Wrocław University of Environmental and Life Sciences. According to typological soil classification, the proper alluvial soils that are typical soil of river valleys dominate in the area of the Agro and Hydrometeorological Observatory in Swojec 
and Research-Development of Vegetables and Ornamental Plants in Psary, Lower Silesia (Poland) [79]. In the international classification FAO-WRB (IUSS 2015), the soils are classified in the reference group of Arenosols (Eutric Fluvic Brunic Arenosols (Aric)) [80]. The soils were prepared to be homogenous, stones and plant roots were sieved, and large soil aggregates were crashed. In Table 1, the soil parameters are shown. The presented outcomes were established at a certified laboratory-Centre for Analyses of the Environmental Quality, as well as at Geotechnical Laboratory, both of which are part of Wrocław University of Environmental and Life Sciences. Three samples were taken, for every soil parameter test, and the results were averaged.

Table 1. Used soil type characteristics.

\begin{tabular}{|c|c|c|c|c|c|}
\hline \multirow[b]{2}{*}{ Parameter } & \multirow[b]{2}{*}{ Unit } & \multirow[b]{2}{*}{ Method } & \multicolumn{3}{|c|}{ Soil Type } \\
\hline & & & $\begin{array}{l}\text { Coarse Sand } \\
\text { (COS) }\end{array}$ & $\begin{array}{l}\text { Loamy Sand } \\
\text { (LS) }\end{array}$ & $\begin{array}{l}\text { Sandy Loam } \\
\text { (SL) }\end{array}$ \\
\hline Silt & $(\%)$ & & 0.06 & 15 & 21 \\
\hline Clay & $(\%)$ & Classification & 0.06 & 7 & 16 \\
\hline Sand & $(\%)$ & acc. to USDA & 98.67 & 78.2 & 59.48 \\
\hline $\mathrm{pH}_{\mathrm{KCl}}$ & $(-)$ & $\begin{array}{c}\text { PN-ISO } \\
\text { 10390:1997(A) }\end{array}$ & $7.5 \pm 0.3$ & $7.4 \pm 0.3$ & $7.6 \pm 0.3$ \\
\hline Salinity & $\left(\mathrm{g} \cdot \mathrm{kg}^{-1} \mathrm{DM}\right)$ & $\begin{array}{c}\text { PBW - 11, PN-ISO } \\
\text { 13878:2002 }\end{array}$ & 0.06 & 0.167 & 0.197 \\
\hline Total Nitrogen (N) & $(\% \mathrm{DM})$ & PN-ISO 13878:2002 & 0.03 & 0.06 & 0.2 \\
\hline Potassium (K) & $\left(\mathrm{g} \cdot \mathrm{kg}^{-1} \mathrm{DM}\right)$ & $\begin{array}{c}\text { PBW - 11, PN-ISO } \\
13878: 2002\end{array}$ & 0.629 & 1.85 & 2.84 \\
\hline Phosphorus (P) & $\left(\mathrm{g} \cdot \mathrm{kg}^{-1} \mathrm{DM}\right)$ & $\begin{array}{c}\text { PBW - 11, PN-ISO } \\
13878: 2002\end{array}$ & 57.1 & 0.519 & 0.801 \\
\hline Magnesium (Mg) & $\left(\mathrm{g} \cdot \mathrm{kg}^{-1} \mathrm{DM}\right)$ & $\begin{array}{c}\text { PBW - 11, PN-ISO } \\
13878: 2002\end{array}$ & 0.343 & 1.84 & 2.75 \\
\hline $\begin{array}{l}\text { Electric } \\
\text { Conductivity (EC) }\end{array}$ & $\left(\mu \mathrm{S} \cdot \mathrm{cm}^{-1}\right)$ & $\begin{array}{c}\text { PN-ISO } \\
\text { 11265+AC1:1997 }\end{array}$ & 30.0 & 123.0 & 429.0 \\
\hline $\begin{array}{l}\text { Soil organic carbon } \\
\text { (SOC) }\end{array}$ & $(\%)$ & Thermal method & 0.36 & 2.86 & 8.66 \\
\hline Bulk density & $\left(\mathrm{g} \cdot \mathrm{cm}^{-3}\right)$ & Weight method & 1.61 & 1.67 & 1.52 \\
\hline
\end{tabular}

Additionally, with the usage of pressure plate apparatus, the soil water retention characteristic was developed. Five samples of each soil were examined and the results were averaged. Water retention characteristic curves with a negative pore water pressure are presented in Figure 1. Soil samples $(n=5)$ were taken for analysis from the test stand container after the conducted research. 


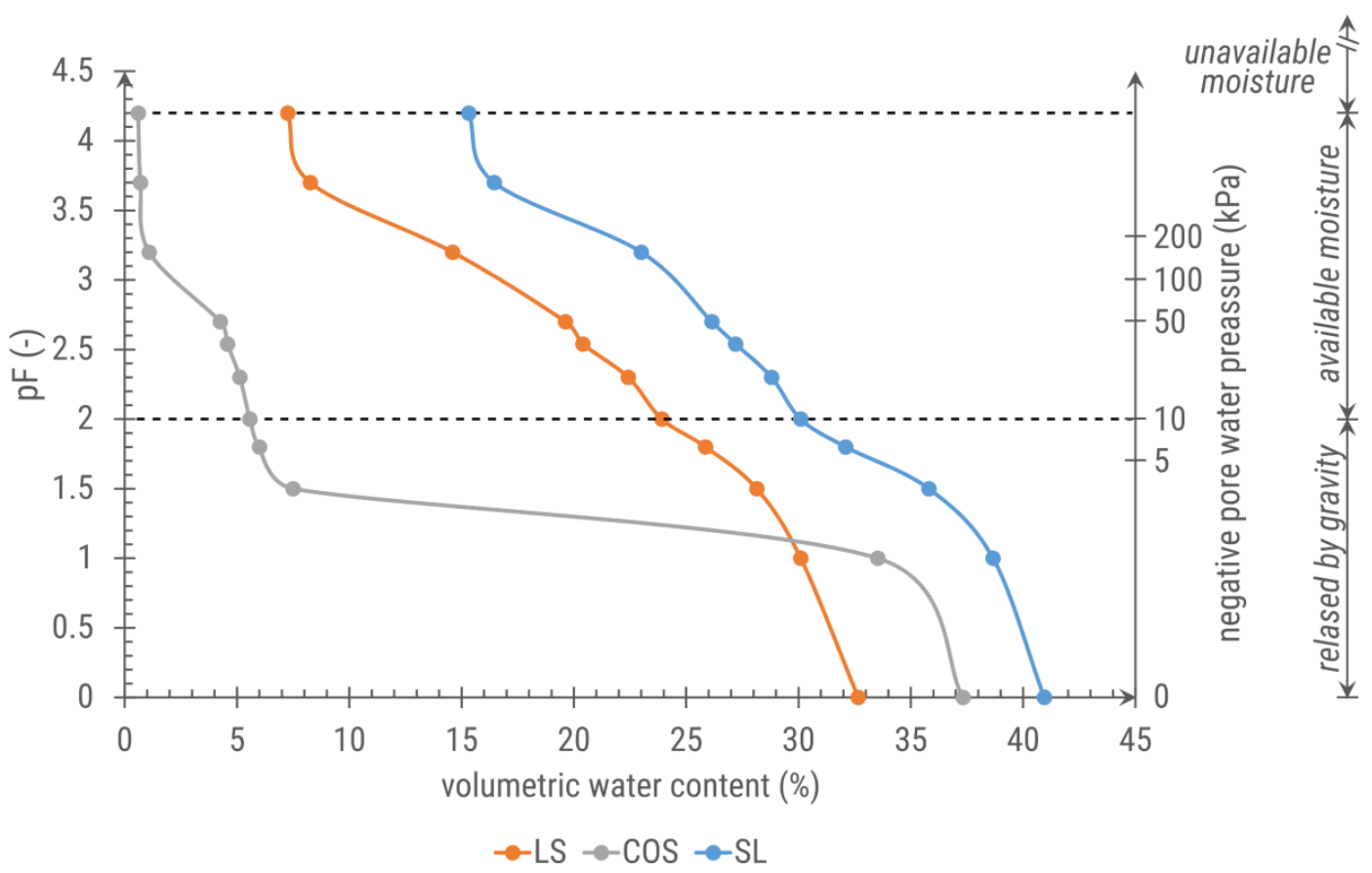

Figure 1. Water retention characteristic for used soils: COS-Coarse Sand, LS-Loamy Sand, SL-Sandy Loam.

\subsection{Used Soil Profiles and WAG Treatment}

Soil profiles were prepared to represent those designed and used in environmental engineering as a topsoil layer or agriculture with respect to the content of organic matter. Three samples were prepared for every type of examined soil profile. One sample was a control and two samples were with a WAG treatment placed at different depths in each sample. Profiles were named according to the type of soil used (COS — coarse sand, LS—loamy sand, SL—sandy loam, and LS+COS-loamy sand+ coarse sand). In the case of the samples with the WAG treatment, a number of 10 or 20 was added to the name, relating to the point depth of the WAG placement in the sample, with 10 for a $10 \mathrm{~cm}$ depth and 20 for a $20 \mathrm{~cm}$ depth for a placement under the top of the soil surface. For better illustration, the soil profiles used are shown in Figure 2.

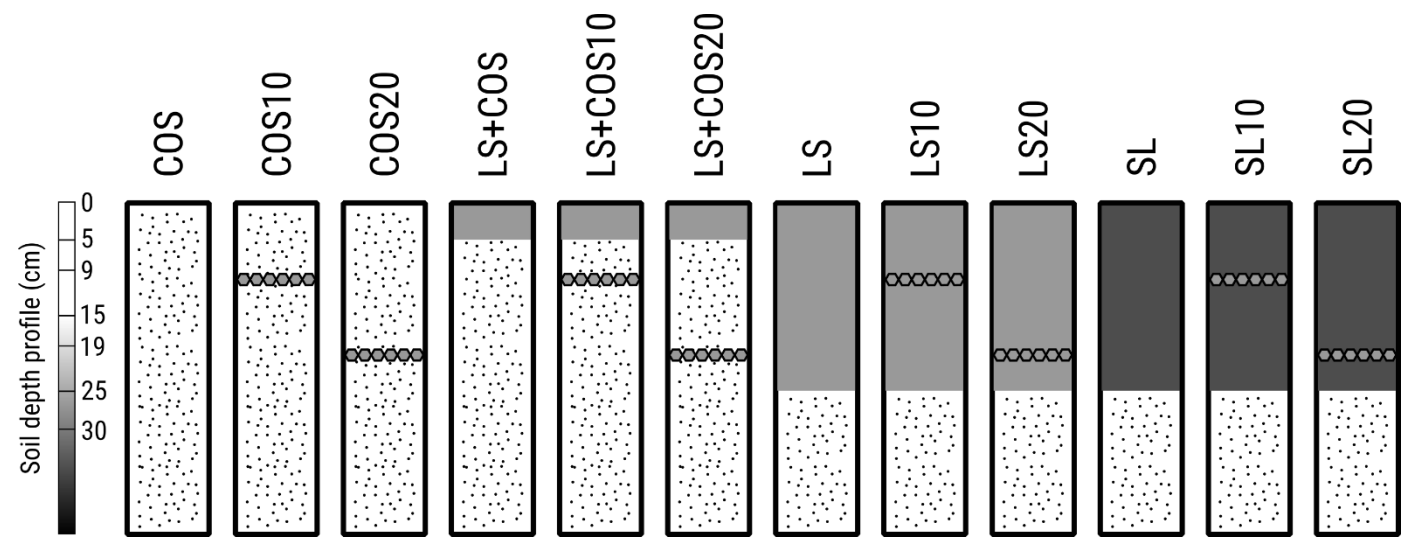

Figure 2. Soil profile variants and the depth of water absorbing geocomposite (WAG) placement. Variant description: COS—coarse sand as a control; COS10 — coarse sand with WAG at a $10 \mathrm{~cm}$ depth; COS20 - coarse sand with WAG at a $20 \mathrm{~cm}$ depth; LS+COS $-5 \mathrm{~cm}$ thick layer of loamy sand on top and the rest of coarse sand, with the profile as a control; LS+COS10 $-5 \mathrm{~cm}$ thick layer of loamy sand on top and the rest of coarse sand, with WAG placed at a $10 \mathrm{~cm}$ depth; LS+COS20 $-5 \mathrm{~cm}$ thick layer 
of loamy sand on top and the rest of coarse sand, with WAG placed at a $10 \mathrm{~cm}$ depth; $\mathbf{L S}+\mathbf{C O S 2 0}-5$ $\mathrm{cm}$ thick layer of loamy sand on top and the rest of coarse sand, with WAG placed at a $20 \mathrm{~cm}$ depth; LS $-25 \mathrm{~cm}$ thick layer of loamy sand and the rest of coarse sand, as a control profile; LS10 $-25 \mathrm{~cm}$ thick layer of loamy sand and the rest of coarse sand, with WAG placed at a $10 \mathrm{~cm}$ depth; LS20-25 cm thick layer of loamy sand and the rest of coarse sand, with WAG placed at a $20 \mathrm{~cm}$ depth; SL-25 cm thick layer of sandy loam and the rest of coarse sand, as a control profile; SL10 $-25 \mathrm{~cm}$ thick layer of sandy loam and the rest of coarse sand, with WAG placed at a $10 \mathrm{~cm}$ depth; SL20-25 cm thick layer of sandy loam and the rest of coarse sand, with WAG placed at a $20 \mathrm{~cm}$ depth.

A water absorbing geocomposite (WAG) in the form of a mat was used in soil profiles as a treatment. The WAG consisted of a nonwoven, synthetic mat skeleton structure and a superabsorbent polymer placed inside the structure. A polyester needle-punched nonwoven geotextile made of $100 \%$ polyester with wicking abilities and a weight of $150 \mathrm{~g} \cdot \mathrm{m}^{-2}$ was used. Available on the market, Aquasorb 3005 KL (SNF FLOERGER, France), a cross-linked copolymer of acrylamide and potassium acrylate, was used as a superabsorbent in the WAG. Table 2 shows additional physical properties of the Aquasorb $3005 \mathrm{KL}$ reproduced from the manufacturer's specifications. At the depths of $10 \mathrm{~cm}$ and $20 \mathrm{~cm}$ under the soil surface inside treated soil profiles, the WAG was placed. Such a location is related to the optimal depth of the geocomposite application and to the extension of the plant's root zone.

Table 2. Important characteristics of the superabsorbent polymer used [81].

\begin{tabular}{lc}
\hline \multicolumn{1}{c}{ Parameter } & Characteristic \\
\hline Chemical constitution & Cross linked copolymer of Acrylamide and Potassium Acrylate \\
Dppearance & Hydrated: transparent gel \\
Particle size & Powders, micro granules, granules \\
$\mathrm{pH}$ & 8.10 \\
Dry matter & $85-90 \%$ \\
Apparent density & 0.85 \\
Specific weight & $1.10 \mathrm{~g} \cdot \mathrm{cm}^{-3}$ \\
Maximum water absorption $(w / w)$ & $980 \mathrm{~mL} \cdot \mathrm{L}^{-1}$ \\
Water retention capacity at $\mathrm{pF} 1$ & $95 \%$ \\
Water retention capacity at $\mathrm{pF} 4.2$ & $4.6 \mathrm{meq} \cdot \mathrm{g}^{-1}$ \\
Cationic Exchange Capacity $(\mathrm{CEC})$ & $\mathrm{Up} \mathrm{to} 5 \mathrm{years}$ \\
Effectiveness in soil & None under normal conditions of use \\
Toxicity in soil & \\
\hline
\end{tabular}

\subsection{Test Stand and Measuring Equipment}

A special test stand was built for the purposes of the experiment. Its construction enabled the main goal of the study to be achieved: testing the moisture content and soil matric potential change in the soil with WAG operating under heating conditions. The test stand consisted of a container able to store soil monolith with dimensions of $105 \times 70 \times 50 \mathrm{~cm}$. The container was made of a $12 \mathrm{~mm}$ thick waterproof oriented strand board which was secured by waterproofing varnish, a layer of thick foil, and geotextile. The construction was equipped with a water providing system, as well as a drainage system. The drainage system was prepared with special care as a fundamental part of the test stand and consisted of two layers of drainage mat wrapped with highly permeable nonwoven fabric, which lay on a wooden board inclined at $2 \%$. Such an inclination guarantees that the water is effectively drained to the drainage valve. Additionally, eight pipes were prepared for water outflow through two valves. At a distance of $1 \mathrm{~m}$ above the soil surface, four heating lamps of $1100 \mathrm{~W}$ were placed so as to simulate the sun heating. The test stand was shown in side views in Figure 3. Beside the test stand, a control board equipped with time-domain reflectometry (TDR) data collection devices and a water supply controller was made. 


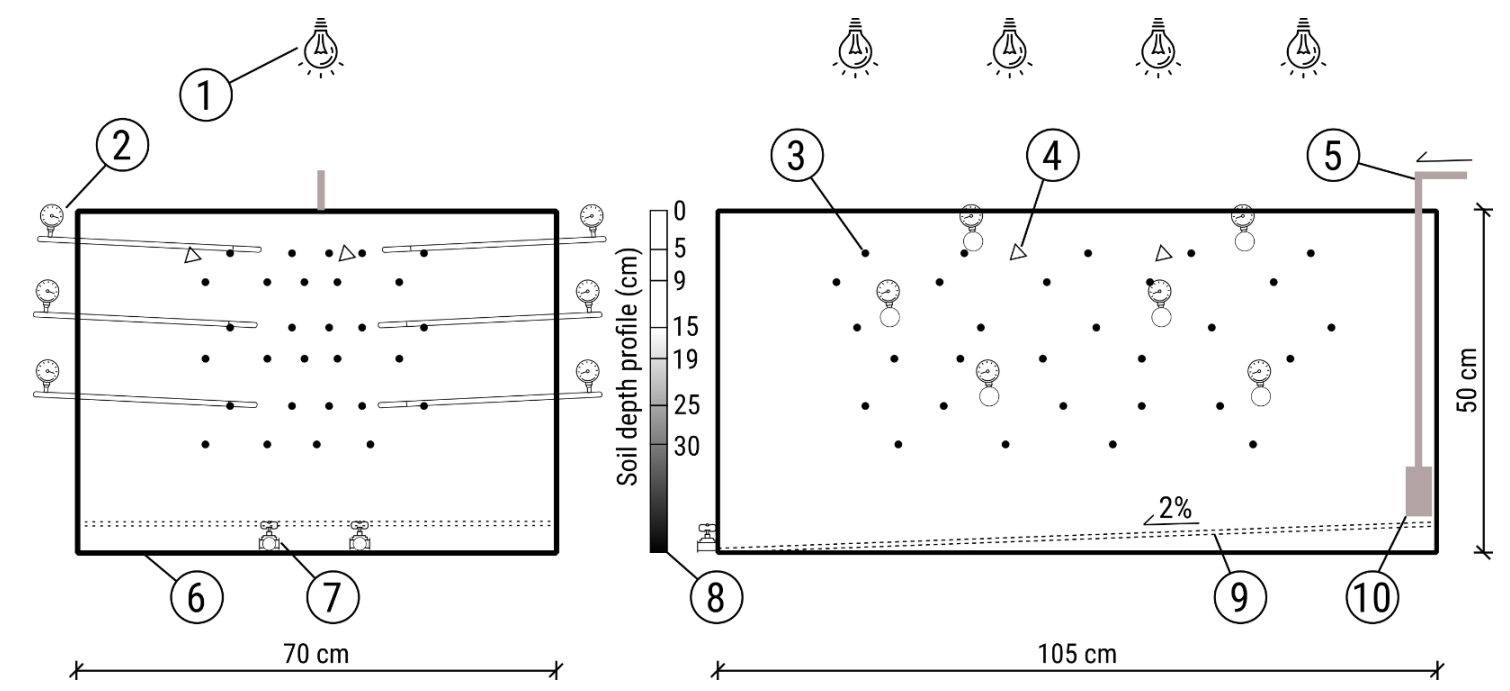

Figure 3. Test stand scheme in two side views with an illustration of the sensor placement positions. Description of numbered positions: 1-heating lamps, 2-tensiometer for soil matric potential, 3-soil moisture content sensor, 4-soil temperature sensor, 5-irrigation system, 6-container, 7-drainage valve, 8 - soil depth profile scale, $9-3 \mathrm{~cm}$ thick drainage mat with $2 \%$ inclination, 10 -watering buffer.

Soil matric potential was measured by field tensiometers manufactured by Irrometer ${ }^{\mathrm{TM}}$ (Riverside, CA, USA), with a $30 \mathrm{~cm}$ long shaft. According to Irrometer тм Company, the analog tensiometer accuracy is $\pm 3-2-3 \%$ ( $3 \%$ at minimum and maximum pressure, $2 \%$ in the middle operating range) of span with a resolution of a $1 \mathrm{kPa}$ reading. Tensiometers were installed horizontally, to receive the measured value from the level in the soil profile at the three depths of 5, 15, and $25 \mathrm{~cm}$ below the top of the soil surface. Before every measurement session, tensiometers were vented, filled with dedicated liquid, and checked by a test service pump. The top two tensiometers were secured from the heat of the heating lamps. Irrometer ${ }^{\mathrm{TM}}$ tensiometers are widely used for soil matric potential measurement [82-85]. Regarding the soil moisture content, it was measured with the use of TDR devices manufactured by E-Test ${ }^{\mathrm{TM}}$ Company. Field probes are accurate: for soil moisture content probes, $\pm 2 \%$, and for temperature probes, $\pm 0.5^{\circ}$. The resolution of the reading for soil moisture content is $0.1 \%$ and for temperature is $0.1^{\circ} \mathrm{C}$. Soil moisture content was recorded at six depths of $5,9,15,19$, 25 , and $30 \mathrm{~cm}$ under the top of the soil surface. At every mentioned level, five probes were installed. The depths of probe installation resulted from WAG placements. Apart from the soil moisture content, the temperature was controlled at the depth of $5 \mathrm{~cm}$ under the soil surface and in the laboratory room to ensure that no problem with heating occurred. The temperature in the laboratory room oscillated between 22 and $24^{\circ} \mathrm{C}$. TDR devices used in this experiment are commonly applied to measure soil moisture content and soil temperature, and their suitability has been proven in the literature [86-90]. The data were recorded with the use of dedicated software delivered with the devices. Considering possible changes of parameters measured close to the edges of the container, all the parameters were measured as close to the centre of the container as possible.

\subsection{The Procedure of Data Collection}

The soil was placed inside the container layer by layer to avoid changes of the soil bulk density caused by the sample preparation process. The container was filled with soil to almost full capacity. A buffer of $3 \mathrm{~cm}$ was left to prevent water spill out from the container during the watering processes. The density of the prepared samples was controlled by the weight of the used soil and the volume of the container with respect to the soil moisture content. Measuring probes were placed at specific levels of the soil profile, and efforts were made to put probes in the central part of the container. The positions and placement of the probes are shown in Figure 3. After filling the container by soil and measuring probe installation, the container was watered with tap water. The watering system was prepared to fill 
the container with water starting from the bottom of the container to its top. This way of watering allowed the air to be pushed out of the soil pores. To avoid destruction of the soil structure by a rapid water flow, the time of watering was one hour. When water appeared on the surface of the soil, it was maintained for $20 \mathrm{~min}$ to ensure that the soil sample was fully saturated and equal hydraulic conductivity was achieved. Afterwards, the container was drained. This procedure of watering and drainage was repeated three times for every sample in order to stabilize bulk density change before starting a measurement session. It is important to note that this mode of sample preparation requires researchers to take into account the changes in the soil layer thickness. Therefore, it is essential to use more soil than appears sufficient to get the specific layer thickness in the end. It is possible to install probes after soil bulk density stabilization with the use of a dedicated soil drill. It would be more appropriate, but it could be difficult, to install probes in the centre of the test container without leaving an empty channel space behind probes made by a soil drill. The measurement session started from sample irrigation and drainage. When water had drained from the soil surface, the heating lamps were switched on, as well as other measuring devices. The test procedure and sample preparation were the same for control samples and samples with WAG treatment. The test procedure was repeated three times for each soil sample.

\subsection{Data Analysis}

The concept of the method presented in this study was based on the research conducted by Narjary at al. [51]. For analysis, the values of soil moisture content and soil matric potential were taken, achieved at 24,48 , and $72 \mathrm{~h}$ from the start of the experiment, which was the moment when water had drained from the soil surface inside the container. However, it was noticed that gravity water drained out the period of two hours from non-cohesive soils and five hours from cohesive soils. Therefore, soil moisture contents when the sample was in a saturated state were excluded from analysis. The collected data were elaborated with software delivered with measuring devices. In the figures, error bars are shown for a standard error of the mean based on three repetitions of the measurement.

\section{Results}

Between the control samples and the samples treated with the WAG, considerable differences were noticed. Soil profile samples with the WAG treatment lost more water than the control samples, particularly in the superficial soil layer above the geosynthetic used. Similarly, the changes in soil matric potential were higher in the samples with the WAG than in the control samples. However, after summarizing water losses in soil profiles and taking into account the water retained in the WAG, it appeared that the samples with the WAG had more water easily available for plants than the control samples. The influence of WAG depth placement on the soil moisture content and soil matric potential was observed.

\subsection{Soil Moisture Content Loss}

In Figure 4, the results of moisture content loss in soil profiles at various depths in a 24-h time step are presented. 
Column A

volumetric moisture content loss (\%)

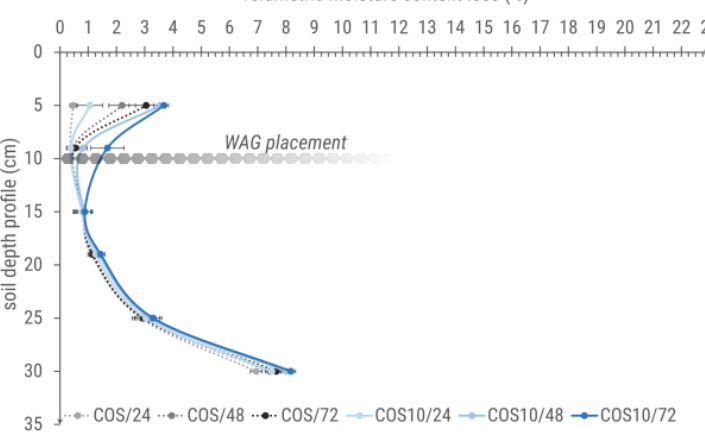

volumetric moisture content loss (\%)
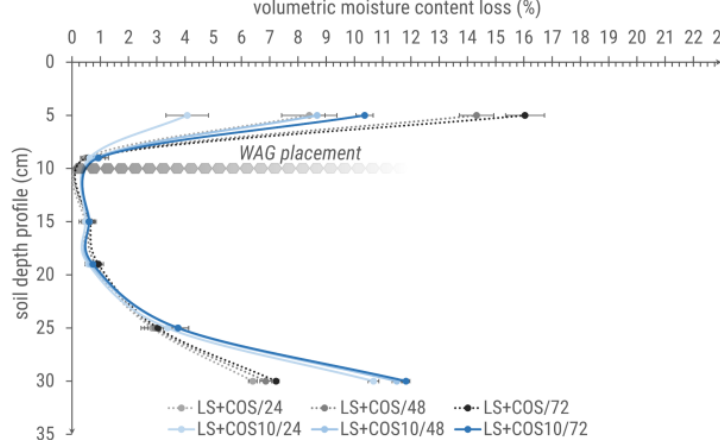

volumetric moisture content loss (\%)

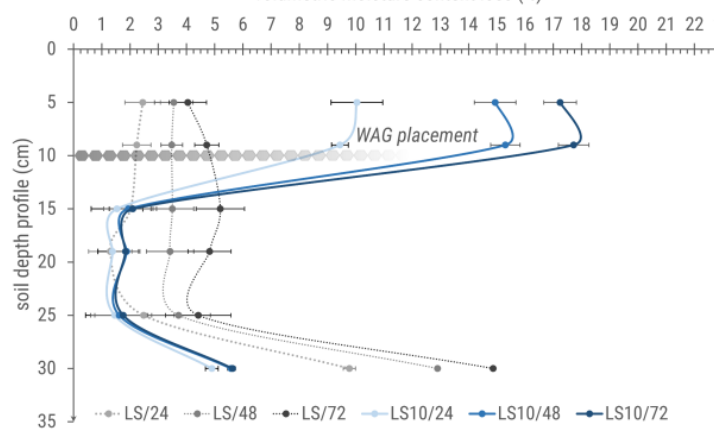

volumetric moisture content loss (\%)

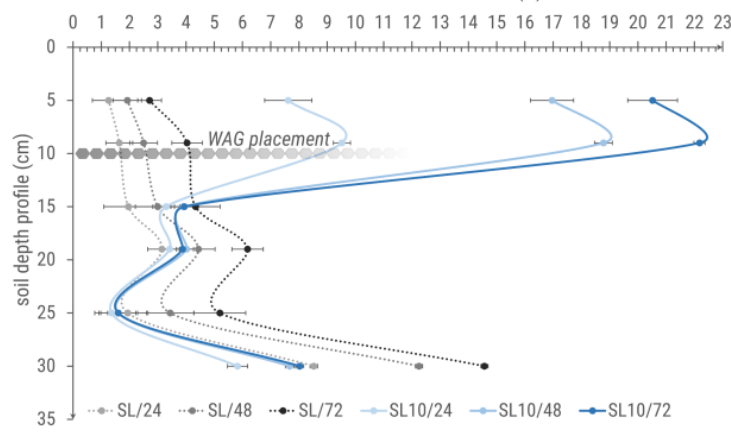

Column B

volumetric moisture content loss (\%)

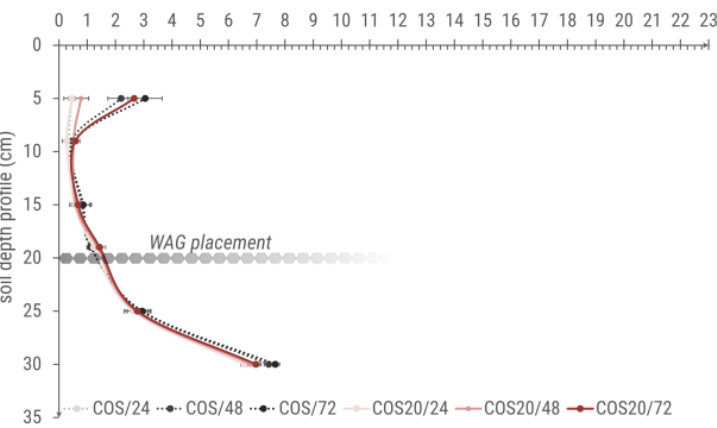

volumetric moisture content loss (\%)

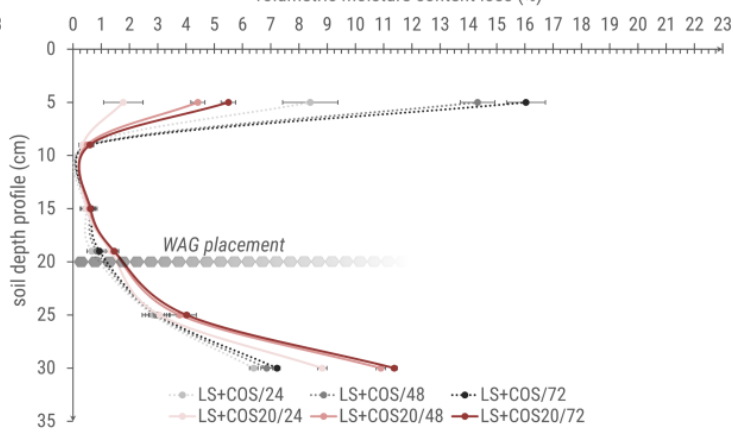

volumetric moisture content loss (\%)

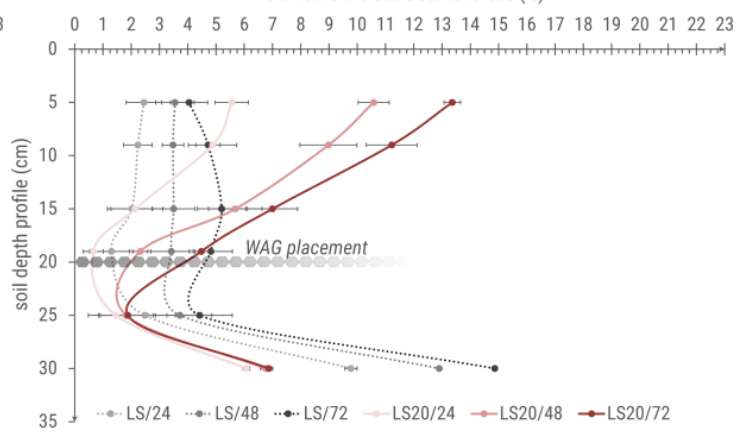

volumetric moisture content loss (\%)

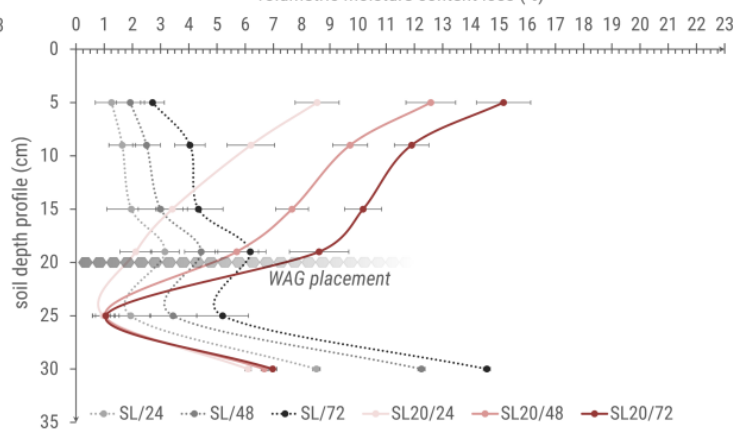

Figure 4. Mean moisture content loss in soil profiles at various depths. Examined samples are presented in a 24-h-long time step described in the legend by the number of hours after a slash. Types of examined soil profiles are described in the legend by use with soil name abbreviation. More detailed information about abbreviations is available in Figure 2. In both columns, control samples are presented in shades of black. Additionally, in column A, the samples with the water absorbing geocomposite (WAG) placed at a $10 \mathrm{~cm}$ depth are presented (shades of blue) and in column $\mathbf{B}$, the samples with the WAG placed at a $20 \mathrm{~cm}$ depth (shades of red) are presented. The mean of three repetitions of the measurement and error bars for standard error of the mean are presented. 
The prepared soil profiles with the use of coarse sand (COS) were made from non-cohesive soil, which is characterized by a low water holding ability. Therefore, moisture content loss was similar in the control samples to that in the samples with WAG treatment. Afterwards, soil profiles (LS+COS) made of a $5 \mathrm{~cm}$ thick layer of loamy sand and coarse sand were examined. The control samples after $72 \mathrm{~h}$ of heating lost $54.8 \%$ more soil moisture content at the depth of $5 \mathrm{~cm}$ than the samples with the WAG treatment placed at a $10 \mathrm{~cm}$ depth and $191.6 \%$ more than the samples with the WAG treatment placed at the depth of $20 \mathrm{~cm}$.

However, the soil profiles made of cohesive soils appeared to be more interesting. In these profiles, the most characteristic changes in soil moisture content were noted at three depths: at a superficial soil layer, at the layer closest to the WAG and at the bottom of the soil profile. Additionally, because of higher water holding abilities, the dynamics of water capacity change in the soils was more apparent. In loamy sand profile titled LS, the amplitude of moisture content loss in the superficial soil layer during 72-h-long heating was also noticeable. For the control sample, amplitude change was 1.6 p.p. (percentage point), but for the sample with the WAG placed at a $10 \mathrm{~cm}$ depth, it was 7.2 p.p. and for the sample with the WAG placed at a $20 \mathrm{~cm}$ depth, it was 7.8 p.p. Furthermore, the WAG placed at a $10 \mathrm{~cm}$ depth decreased the moisture content by $325.7 \%$ in reference to the control samples. For the WAG placed at $20 \mathrm{~cm}$, it was $229.9 \%$. In the samples made of sandy loam named SL, similar dependencies were found. After the 72-h-long heating process in the superficial soil layer, the control samples lost 2.7 p.p. of soil moisture content. In comparison to the samples with the WAG placed at $10 \mathrm{~cm}$, it was 20.5 p.p., and for the WAG at $20 \mathrm{~cm}$, it was 15.2 p.p., of soil moisture content loss. These losses were the highest from all examined soil profiles and present a difference of $660 \%$ for the WAG at $10 \mathrm{~cm}$ and $461.5 \%$ for the WAG placed at $20 \mathrm{~cm}$.

Another interesting fact was that soil moisture content sensors placed close to and above the WAG recorded higher moisture content loss generated by the WAG placed at the depth of $10 \mathrm{~cm}$, which is easily noticeable in the figures presenting cohesive soils (SL and LS). Finally, at the bottom of the soil profiles, differences in soil moisture content between the control samples and the samples with the WAG treatment were noted. The control samples exhibited higher soil moisture content losses than the samples with the WAG.

\subsection{Soil Matric Potential}

The measured values of soil matric potential (negative pressure potential) underline a solid influence of the presence of WAG, especially in cohesive soil profiles. Basically, the changes of soil matric potential in the control samples were slight, but in the samples with the WAG, regardless of the WAG's placement depth, they were significant. In sandy loam profiles (SL) after $24 \mathrm{~h}$ at the depth of $5 \mathrm{~cm}$, the soil matric potential in the samples with the WAG placed at $10 \mathrm{~cm}$ was $25.9 \%$ and for the WAG placed at $20 \mathrm{~cm}$, it was $135.9 \%$ higher compared to the control samples. However, after the next $24 \mathrm{~h}$, the difference in pressure potential increased respectively by about $713 \%$ for the WAG at $10 \mathrm{~cm}$ and only $346.3 \%$ for the WAG at $20 \mathrm{~cm}$. The process of the soil matric potential increase was steadier for the samples with a deeper-placed WAG. However, after $72 \mathrm{~h}$, the pressure potential value, in the superficial soil layer, in the samples with the WAG placed at $20 \mathrm{~cm}$, reached $-79 \mathrm{kPa}$ and in the samples with the WAG placed at $10 \mathrm{~cm}$, reached $-91 \mathrm{kPa}$, while in the control samples, it was maintained at a value of $-10 \mathrm{kPa}$.

Similar results were obtained for the second cohesive profile type examined in the experiment, i.e., the loamy sand profile (LS). The samples with the WAG placed at a $20 \mathrm{~cm}$ depth induced lower pressure potential in the superficial soil layer than the samples with the WAG placed at $10 \mathrm{~cm}$. An intriguing fact was that in the samples treated with the WAG, despite 72-h-long heating, the soil matric potential was significantly lower under the placed WAG than above it. During the experiment, the amplitude of soil matric potential change in the control samples of both types of cohesive soil was dramatically low. Pressure potential oscillated at the value of $-10 \mathrm{kPa}$. The results of soil matric potential measurement are shown in Figure 5. 
Column A

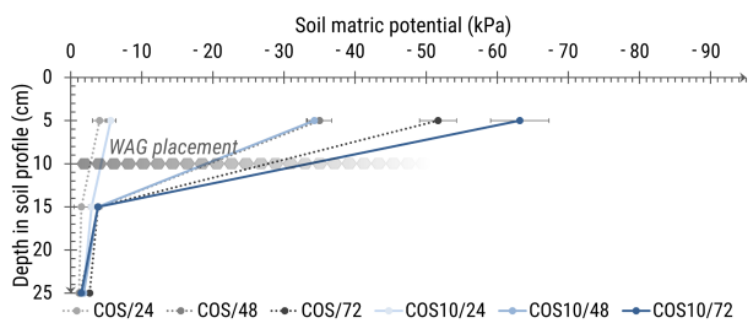

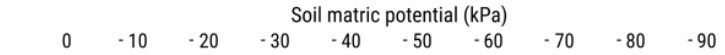
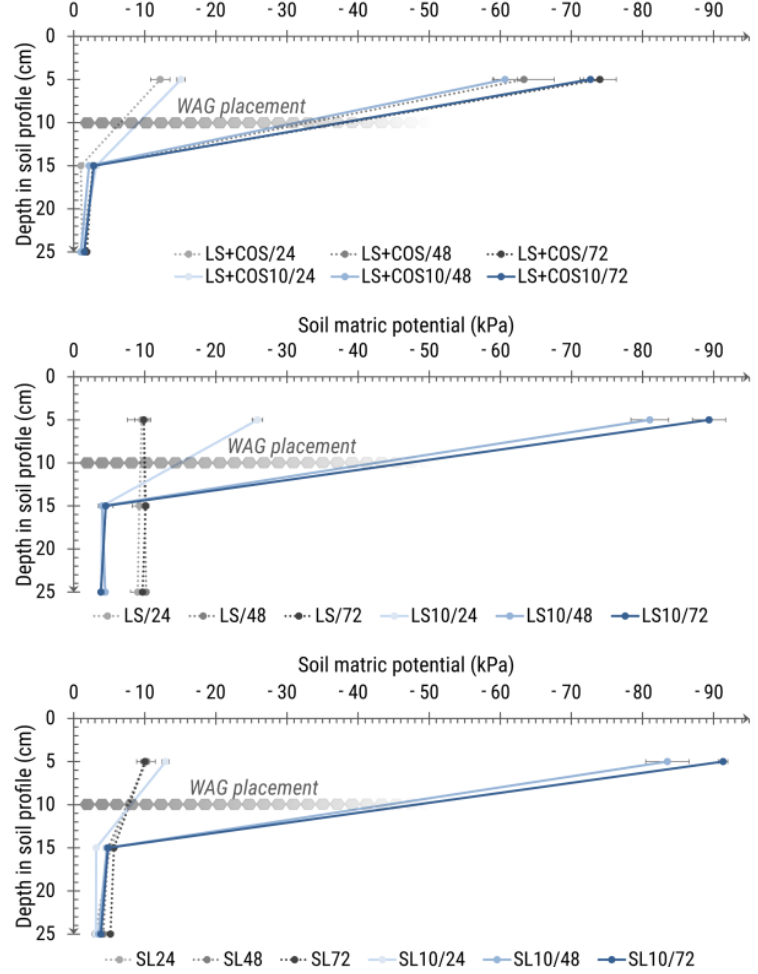

Column B
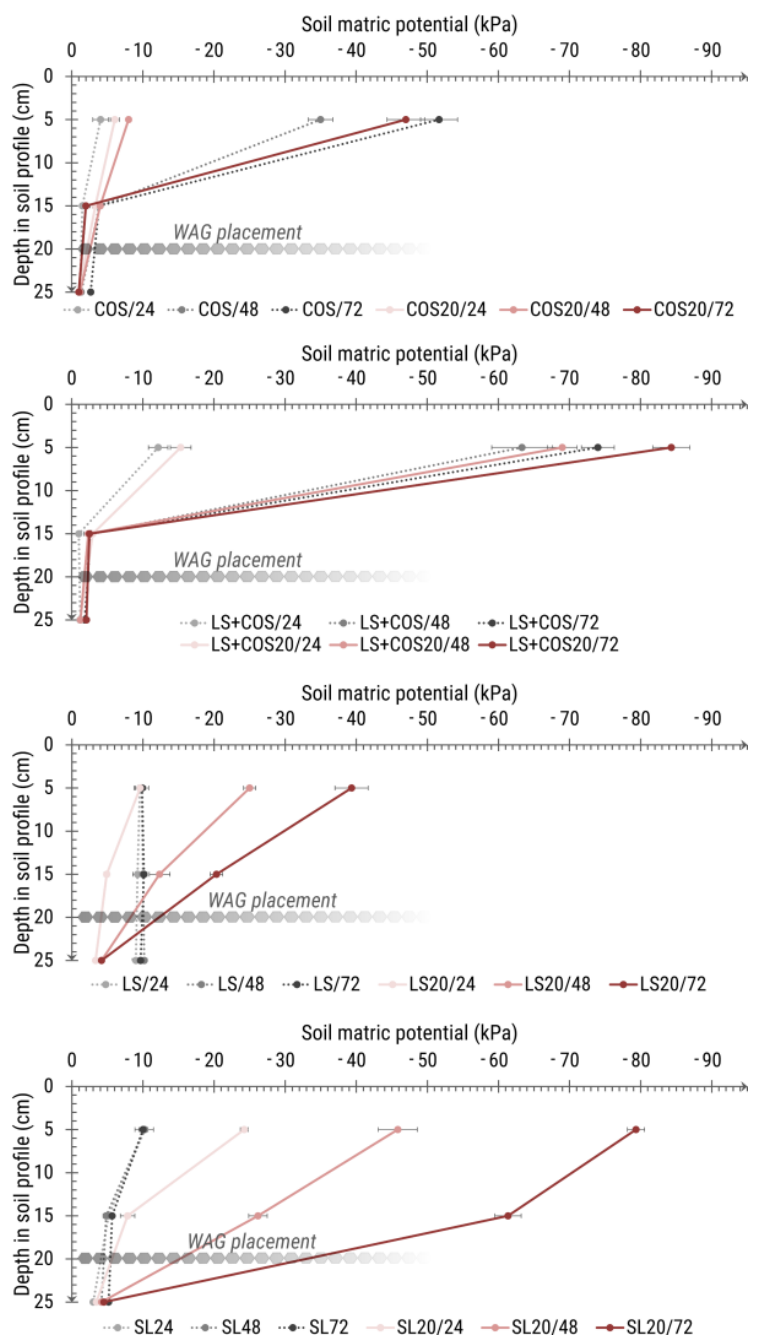

Figure 5. Soil matric potential. Examined samples are presented in a 24-h-long time step described in the legend by the number of hours after a slash. Types of examined soil profiles are described in the legend with soil name abbreviation. More detailed information about abbreviations is available in Figure 2. In both columns, control samples are presented in shades of black. Additionally, in column A, the samples with the water absorbing geocomposite (WAG) placed at a $10 \mathrm{~cm}$ depth are presented (shades of blue) and in column B, the samples with the WAG placed at a $20 \mathrm{~cm}$ depth (shades of red) are presented. The mean of three repetitions of the measurement and error bars for standard error of the mean are presented.

\subsection{Summarized Water Loss in the Soil Profile}

The summary of water losses was prepared in order to get a full spectrum of the WAG effect on water availability in the examined soil profiles. The elaborated data are shown in Figure 6. 
Column A
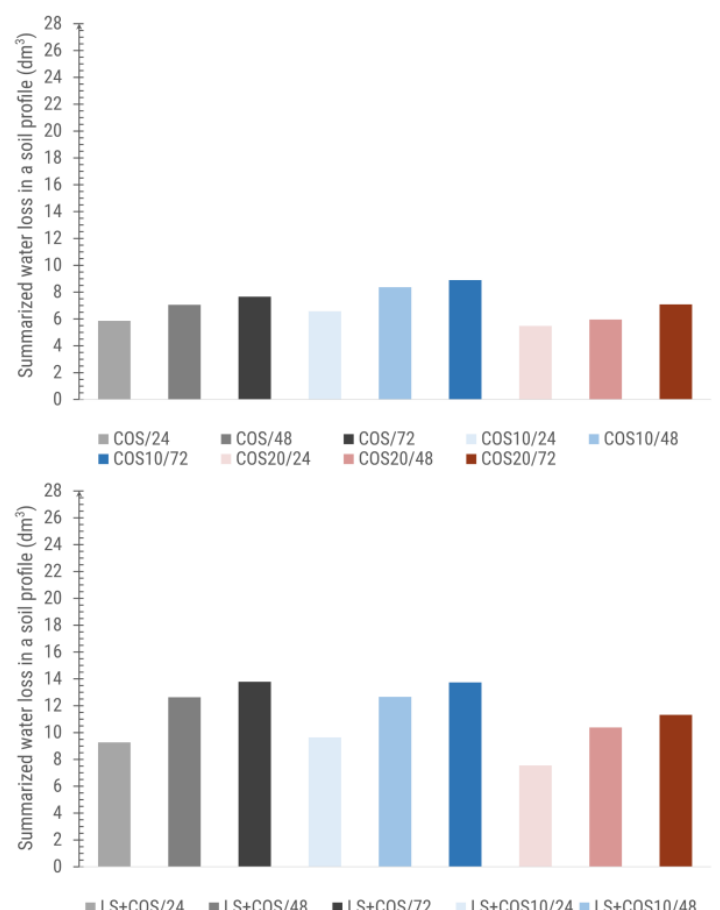

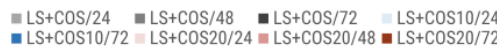
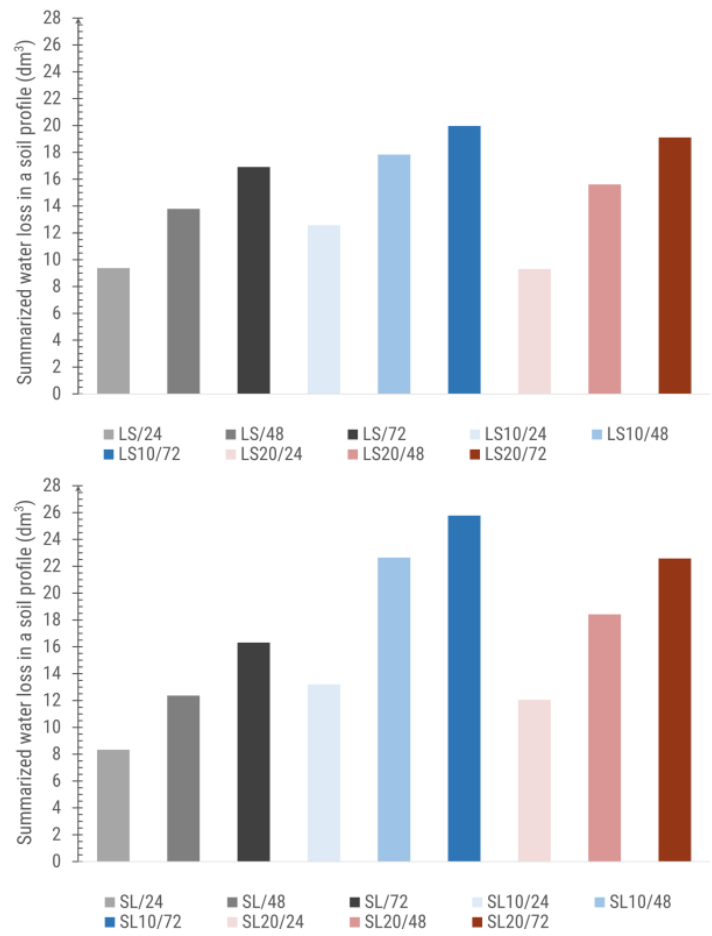

Column B
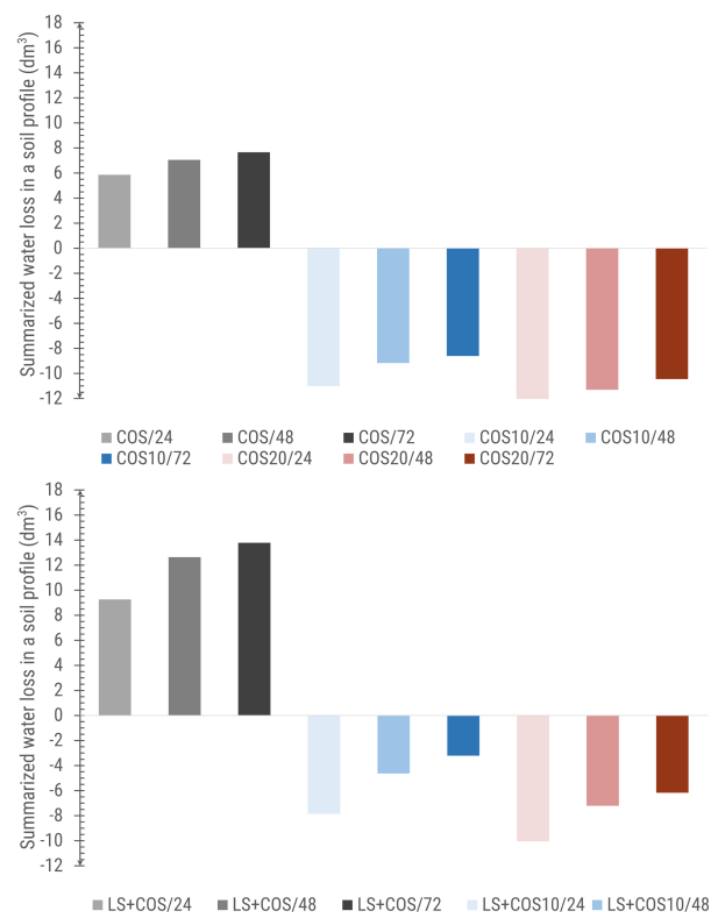

- LS+COS10/72 $=\mathrm{LS}+\operatorname{COS} 20 / 24=\mathrm{LS}+\mathrm{COS} 20 / 48=\mathrm{LS}+\mathrm{COS} 20 / 72$
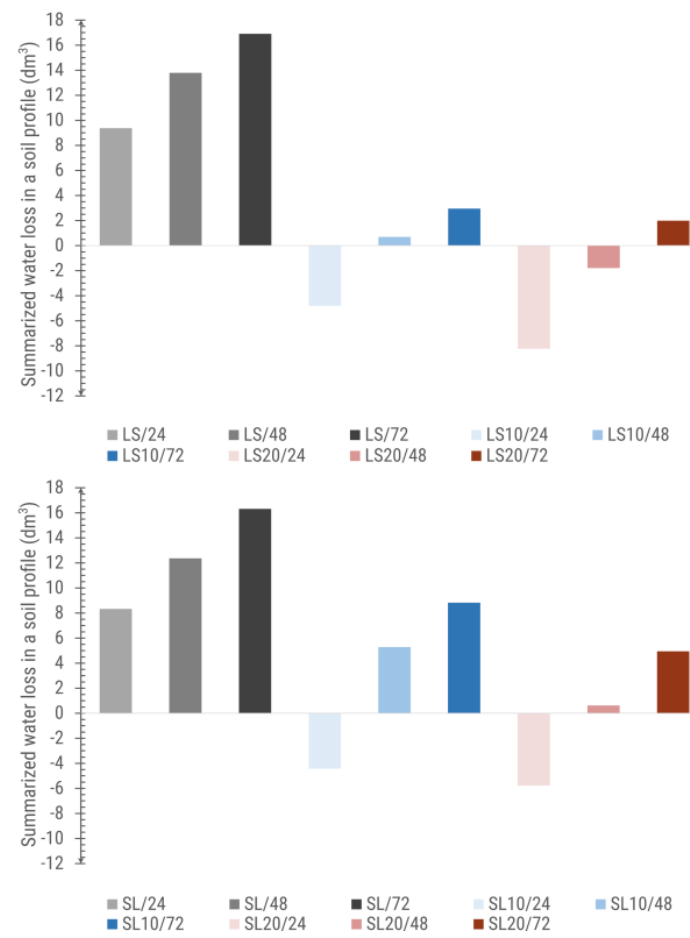

Figure 6. Summarized water losses in soil profiles in reference to the time step. Column A presents the samples without taking into account the water retained in the water absorbing geocomposite (WAG). In column B, the water retained in the WAG has been included. Take note that the negative values in column B mean a surplus in the water budget of the examined soil profile. Examined samples are presented in a 24-h-long time step described in the legend by the number of hours after a slash. Types of examined soil profiles are described in the legend with soil name abbreviation. More detailed information about abbreviations is available in Figure 2. In both columns, control samples are presented in shades of black, samples with the WAG placed at a $10 \mathrm{~cm}$ depth are presented in shades of blue, and the samples with the WAG placed at a $20 \mathrm{~cm}$ depth are shown in shades of red. 
The results illustrated in column A suggest that water losses were greater in soil profiles with the WAG present. However, after including the water retained in the WAG in analyses, it appears that soil profiles treated with WAG contain water more easily available for plants. Water is absorbed by the superabsorbent polymer and stored in the form of gel inside the WAG. The highest water losses were obtained in cohesive soils. In SL profiles with the WAG, losses were about $57.9 \%$ higher for SL10 and $38.4 \%$ higher for SL20 than in the control samples after $72 \mathrm{~h}$. However, taking into account the water retained in the WAG, the profiles with the WAG lost over $46 \%$ for SL10 and $69.7 \%$ for SL20 less water compared to the control sample after $72 \mathrm{~h}$, which might also be presented as $7.5 \mathrm{dm}^{3}$ for WAG10 and $11.4 \mathrm{dm}^{3}$ for WAG20 of water preserved in the samples. In control soil profiles made of loamy sand (LS), more water was retained in the soil, but again, considering the water retained inside the WAG, it appears that the LS10 profile retained $14 \mathrm{dm}^{3}$ and LS20 $15 \mathrm{dm}^{3}$ of water in the soil profile. In non-cohesive soil profiles, the differences between treated and control samples were the most visible. This is especially true in the COS profiles, where, after $72 \mathrm{~h}$, the profiles with the WAG saved about $212.4 \%$ for COS10 and $236.4 \%$ for COS20 more water than the control samples, including the water in the WAG. Additionally, considering the water captured in the WAG, a better performance in water retention was proven by the WAG placed at $20 \mathrm{~cm}$ in all cases.

\section{Discussion}

A water absorbing geocomposite was developed to support plant vegetation in environmental engineering applications, as well in agriculture. Therefore, WAG was designed to retain water and to limit infiltration into the soil profile. Positive effects of WAG's usage, in the shape of point and linear, described earlier in the introduction, contributed to the creation of WAG in the form of a mat. Gathered data during the conducted research confirm that WAG in a mat shape present in the soil significantly influences the soil moisture content and soil matric potential. Moreover, the findings from this study suggest that the type of WAG used induces a capillary barrier in the soil where upward water movement might not occur.

Surprisingly, a water absorbing geocomposite (in the form of a mat) shallowly placed in the soil leads to dryness of the superficial soil layer. Indeed, in fine textured soil, e.g., sandy loam, the loss of volumetric moisture content was higher compared to the control samples. The loss of soil moisture content in the samples is linked with the increased soil matric potential. In the control samples, it was stable at the value of $-10 \mathrm{kPa}$, whereas in the case of the treated samples, it significantly rose to $-79 \mathrm{kPa}$ (WAG20) and $-93 \mathrm{kPa}$ (WAG10) after $72 \mathrm{~h}$ of heating. Albeit, the changes in soil moisture and soil matric potential in the soil profile under the WAG, independently of the WAG placement's depth, slightly differed from the control samples. Additionally, in the control samples at the lowest measured depth, high differences in soil moisture content were noted. The control samples lost ca. 7 p.p. more volumetric moisture content after $72 \mathrm{~h}$ of heating. Interestingly, the water absorbing geocomposite in the form of a mat aimed to support plant-caused soil dryness in the superficial soil layer. A similar behaviour was established for other examined soil profiles. It was found that the mechanism which occurred in the conducted experiment was probably caused by a capillary barrier effect [91-94].

This phenomenon of a barrier for water flow appears mostly in unsaturated soils where differences in soil textures and layering are noted or where geosynthetics are used. According to McCartney and Zornberg, an unsaturated state when geosynthetics are hydraulically non-conductive happens when the matric potential measured between geosynthetic and soil (at the interface) is lower than $-1 \mathrm{kPa}$ [95]. Therefore, in the conducted experiment, the WAG should be considered as a capillary barrier as well. This implies the situation of a capillary barrier when, in the soil layer above drainage or geotextile, the infiltration water might be stored until the layer becomes fully saturated [96-98]. This would probably happen, but differently from the results obtained by other researchers, in the experiment described in this article, the samples were examined during a drying process forced by intensive heating which simulated the sun operation. Hence, the superficial soil layer was dried more significantly, which had not been noted before by other researchers. The capillary barrier is not in a 
permanent state in the soil, and after saturation, when the soil matric potential at the interface is in equilibrium, a breakthrough suction occurs, which initiates a water flow through the abovementioned capillary barrier [99]. Accordingly, knowing that the test container was filled with water, we can assume that the water permeability of the WAG in a state of full saturation is possible.

Beyond infiltration, we have distinguished upward water movements like capillary water rise and evaporation, which may occur separately or together. In the control samples of sandy loams, the oscillations between moisture content in the soil profile were slight, except for a drainage layer made of coarse sand at the bottom of the test container. This points to the fact that upward water movement occurred. Soil matric potential generated in fine texture soil of the upper part of the container triggered upward water movement and caused 7 p.p. volumetric soil moisture content loss from the bottom layer. The water capillary rose to the top of the soil surface, where it evaporated. However, these kinds of upward water movements might also be disturbed by the capillary barrier [100,101]. In the samples with WAG, regardless of its placement, a capillary rise did not occur above the applied geosynthetic. Firstly, this is because of a capillary barrier and high temperature exposition, which drive the evaporation of water accumulated in the upper soil layer, and secondly, this is because of WAG water retaining qualities like wicking nonwoven fabric and superabsorbent polymer. Accordingly, in fine-textured soil profiles where WAG10 was used, soil moisture content probes at the depth of $9 \mathrm{~cm}$ recorded about 2 p.p. higher volumetric soil moisture content loss than at the depth of $5 \mathrm{~cm}$. The obtained results suggested that the only possible upward water movement in the overlying dry layer is an evaporation process, which was observed by Lehmann, Steenhuis and Shokri [101-103].

The evaporation occurring in the soil in which WAG was applied was also studied by Lejcuś et al. [104]. He proved, in a pot experiment, that total water loss from the soil with WAG and sandy soil and loamy soil was significantly lower than from the soil alone. The application of WAG allowed water loss due to evaporation to be limited to about $10 \%$, whereas in the control samples, water loss due to evaporation was recorded at $59 \%$. However, Lejcuś et al. did not study the distribution of moisture in the soil profile, only the weight of the whole pot in total (soil+WAG). It is worth noting that in Lejcuś's experiment, the behavior of samples was studied in the climatic chamber. The conducted research was oriented at estimating evaporation which happened due to an increased temperature of the environment $\left(35-40{ }^{\circ} \mathrm{C}\right.$ during the day and $20-25^{\circ} \mathrm{C}$ during the night). The current study, which verified WAG operating under heating conditions where the soil surface was heated by lamps, shows a similar tendency in the achieved results, i.e., WAG's ability to retain water in the soil profile. However, it also shows that in extreme climate conditions, WAG in the form of a mat in the layer $0-20 \mathrm{~cm}$, may lead to partial drying of that layer, which is emphasized in the conclusions of this article.

The topic of WAG relations with plants should also be discussed in this work. The main objective of the WAG invention is to retain water in the top soil layer, which, without the presence of WAG, could infiltrate into the profile or evaporate. In the experiment described in this article, the main focus was on investigating the behavior of WAG operating under heating conditions in different soils, excluding plants, in order to better understand the interactions between WAG and soil. Certainly, the obtained results of soil moisture distribution would have been influenced by plants, had they been used; however, such results could be difficult to interpret. Numerous experiments conducted previously have confirmed the beneficial effect of WAG on the condition of plants subjected to stress drought. The experiment conducted on Siberian bugloss (Brunnera macrophylla) perennial showed that the application of WAG enabled up to $60 \%$ leaf growth (the number of leaves) and the growth of the biomass of the above-ground parts of plants increased up to $340 \%$ in comparison to plants treated by fertilizers only [105]. In the case of studies conducted on slopes of earth structures, the use of WAG allowed for an increase in root volume up to $130 \%$ and in maximum root length up to $29 \%$. The dry mass of above-ground parts increased in comparison to the field without WAG by $50-73 \%$ and above-ground biomass increased by 58-83\% [72]. Moreover, an experiment carried out on a slope with a different exhibition (in a mineral resources mine) showed that WAG also achieved an increase in 
the height of grass of approx. $10 \mathrm{~cm}$, an average root diameter of $35 \%$, a root volume increase of $39 \%$, and a fresh biomass harvested increase of $36 \%$, compared to the control [74].

Innovative technology such as WAG and water movement in unsaturated soil profiles is still an interesting area for further investigation. Future studies will focus in particular on the influence of WAG in the continuum soil-WAG-soil-plant-atmosphere. Soil electric conductivity measurement would be worth considering in order to assess the salinity level which might occur due to dry-wetting cycles. Furthermore, if the design of the soil profile requires a geosynthetic to be placed shallowly, WAG could be used with a different nonwoven characterized by lower wicking abilities. Future research on the wicking behavior of different nonwovens in comparison to various soil textures might be considered as well.

\section{Conclusions}

In terms of climate change and temperature rise, bearing in mind that water scarcity and drought are one of the main factors of plant stress, a new geosynthetic with a water retention ability was developed. Therefore, the influence of a water absorbing geocomposite in the form of a mat on the soil moisture content and matric potential was assessed. Based on the results of this study, the following can be concluded:

- The results of the conducted research illustrate a phenomenon of the capillary barrier. It was proven that the use of a water absorbing geocomposite in the form of a mat, despite high water retention abilities, might lead to the formation of a capillary barrier in the soil profile. Furthermore, WAG in the form of a mat might cause soil dryness of the layer above the applied geosynthetic, especially when it is shallowly placed. However, it was found that, regardless of the induced dryness, significantly more water was available for plants in the soil profiles with the WAG treatment when the water retained in the WAG was included in the water budget;

- Water absorbing geocomposite should not be used in the form of a full mat in fine-textured soils, especially when, above and under the geosynthetic, there is a cohesive soil layer. However, a mat geocomposite might be used with spaces in the surface to allow the hydraulic conductivity to be maintained. The application of a full-mat WAG might lead to a capillary barrier phenomenon in the soil profile, even where evaporation is limited. However, it is not so crucial in soil profiles where a sandy textured soil layer is designed under the geosynthetic, as on the road slopes. In fine textured soils, a minimal application depth should be established at $20 \mathrm{~cm}$.

\section{Patents}

The presented results were obtained on patent use: “Geocomposite element, particularly for enhancing plant growth", EP2560472, PL211198, which was commercialized in 2012.

Author Contributions: Conceptualization, M.Ś., K.L. and D.G.; Data curation, M.Ś.; Formal analysis, M.Ś.; Funding acquisition, M.Ś., J.D. and D.G.; Investigation, M.Ś. and A.B.; Methodology, M.Ś.; Resources, M.Ś. and D.G.; Supervision, M.Ś.; Validation, K.L., J.D. and A.B.; Visualization, M.Ś.; Writing—original draft, M.Ś.; Writing一review \& editing, M.Ś. and J.D.

Funding: This research was funded by the Faculty of Environmental Engineering and Geodesy, Wrocław University of Environmental and Life Sciences, grant number: B030/0099/17.

Acknowledgments: The project is financed under the program of the Minister of Science and Higher Education "Strategy of Excellence-University of Research" in 2018-2019 project number 0019/SDU/ 2018/18 in the amount of PLN 700,000.

Conflicts of Interest: The authors declare no conflicts of interest. 


\section{References}

1. Szewranski, S.; Chruscinski, J.; Kazak, J.; Swiader, M.; Tokarczyk-Dorociak, K.; Zmuda, R. Pluvial Flood Risk Assessment Tool (PFRA) for Rainwater Management and Adaptation to Climate Change in Newly Urbanised Areas. Water 2018, 10, 386. [CrossRef]

2. Kaushal, S.S.; Gold, A.J.; Mayer, P.M. Land Use, Climate, and Water ResourcesGlobal Stages of Interaction. Water 2017, 9, 815. [CrossRef] [PubMed]

3. Godfray, H.C.J.; Beddington, J.R.; Crute, I.R.; Haddad, L.; Lawrence, D.; Muir, J.F.; Pretty, J.; Robinson, S.; Thomas, S.M.; Toulmin, C. Food Security: The Challenge of Feeding 9 Billion People. Science 2010, 327, 812-818. [CrossRef] [PubMed]

4. Hanjra, M.A.; Qureshi, M.E. Global water crisis and future food security in an era of climate change. Food Policy 2010, 35, 365-377. [CrossRef]

5. Zhang, L.T.; Gao, Z.L.; Yang, S.W.; Li, Y.H.; Tian, H.W. Dynamic processes of soil erosion by runoff on engineered landforms derived from expressway construction: A case study of typical steep spoil heap. Catena 2015, 128, 108-121. [CrossRef]

6. Koda, E.; Pachuta, K.; Osinski, P. Potential of Plant Applications in the Initial Stage of the Landfill Reclamation Process. Pol. J. Environ. Stud. 2013, 22, 1731-1739.

7. Vannoppen, W.; Vanmaercke, M.; De Baets, S.; Poesen, J. A review of the mechanical effects of plant roots on concentrated flow erosion rates. Earth Sci. Rev. 2015, 150, 666-678. [CrossRef]

8. Zhang, L.; Wang, J.M.; Bai, Z.K.; Lv, C.J. Effects of vegetation on runoff and soil erosion on reclaimed land in an opencast coal-mine dump in a loess area. Catena 2015, 128, 44-53. [CrossRef]

9. Trenberth, K.E.; Dai, A.G.; van der Schrier, G.; Jones, P.D.; Barichivich, J.; Briffa, K.R.; Sheffield, J. Global warming and changes in drought. Nat. Clim. Chang. 2014, 4, 17-22. [CrossRef]

10. Greco, R.; Guida, A.; Damiano, E.; Olivares, L. Soil water content and suction monitoring in model slopes for shallow flowslides early warning applications. Phys. Chem. Earth 2010, 35, 127-136. [CrossRef]

11. Bochet, E.; Garcia-Fayos, P. Factors controlling vegetation establishment and water erosion on motorway slopes in Valencia, Spain. Restor. Ecol. 2004, 12, 166-174. [CrossRef]

12. Osman, N.; Barakbah, S.S. The effect of plant succession on slope stability. Ecol. Eng. 2011, 37, $139-147$. [CrossRef]

13. Li, M.H.; Eddleman, K.E. Biotechnical engineering as an alternative to traditional engineering methods-A biotechnical streambank stabilization design approach. Landsc. Urban Plan. 2002, 60, 225-242. [CrossRef]

14. Bomers, A.; Lopez, J.P.A.; Warmink, J.J.; Hulscher, S. Modelling effects of an asphalt road at a dike crest on dike cover erosion onset during wave overtopping. Nat. Hazards 2018, 93, 1-30. [CrossRef]

15. Bolte, K.; Hartmann, P.; Fleige, H.; Horn, R. Determination of critical soil water content and matric potential for wind erosion. J. Soils Sediments 2011, 11, 209-220. [CrossRef]

16. Kokutse, N.K.; Temgoua, A.G.T.; Kavazovic, Z. Slope stability and vegetation: Conceptual and numerical investigation of mechanical effects. Ecol. Eng. 2016, 86, 146-153. [CrossRef]

17. Tosi, M. Root tensile strength relationships and their slope stability implications of three shrub species in the Northern Apennines (Italy). Geomorphology 2007, 87, 268-283. [CrossRef]

18. De Baets, S.; Poesen, J.; Reubens, B.; Wemans, K.; De Baerdemaeker, J.; Muys, B. Root tensile strength and root distribution of typical Mediterranean plant species and their contribution to soil shear strength. Plant Soil 2008, 305, 207-226. [CrossRef]

19. Dabney, S.M.; Shields, F.D.; Temple, D.M.; Langendoen, E.J. Erosion processes in gullies modified by establishing grass hedges. Trans. ASAE 2004, 47, 1561-1571. [CrossRef]

20. Hudek, C.; Sterk, G.; van Beek, R.; de Jong, S.M. Modelling soil erosion reduction by Mahonia aquifolium on hillslopes in Hungary: The impact of soil stabilization by roots. Catena 2014, 122, 159-169. [CrossRef]

21. Osman, N.; Barakbah, S.S. Parameters to predict slope stability-Soil water and root profiles. Ecol. Eng. 2006, 28, 90-95. [CrossRef]

22. Tron, S.; Dani, A.; Laio, F.; Preti, F.; Ridolfi, L. Mean root depth estimation at landslide slopes. Ecol. Eng. 2014, 69, 118-125. [CrossRef]

23. Eapen, D.; Barroso, M.L.; Ponce, G.; Campos, M.E.; Cassab, G.I. Hydrotropism: Root growth responses to water. Trends Plant Sci. 2005, 10, 44-50. [CrossRef] 
24. Bodner, G.; Nakhforoosh, A.; Kaul, H.P. Management of crop water under drought: A review. Agron. Sustain. Dev. 2015, 35, 401-442. [CrossRef]

25. Elia, G.; Cotecchia, F.; Pedone, G.; Vaunat, J.; Vardon, P.J.; Pereira, C.; Springman, S.M.; Rouainia, M.; Van Esch, J.; Koda, E.; et al. Numerical modelling of slope-vegetation-atmosphere interaction: An overview. $Q$. J. Eng. Geol. Hydrogeol. 2017, 50, 249-270. [CrossRef]

26. Tang, A.M.; Hughes, P.N.; Dijkstra, T.A.; Askarinejad, A.; Brenčič, M.; Cui, Y.J.; Diez, J.J.; Firgi, T.; Gajewska, B.; Gentile, F.; et al. Atmosphere-vegetation-soil interactions in a climate change context; impact of changing conditions on engineered transport infrastructure slopes in Europe. Q. J. Eng. Geol. Hydrogeol. 2018, 51, 156-168. [CrossRef]

27. Alvarez-Mozos, J.; Abad, E.; Goni, M.; Gimenez, R.; Campo, M.A.; Diez, J.; Casali, J.; Arive, M.; Diego, I. Evaluation of erosion control geotextiles on steep slopes. Part 2: Influence on the establishment and growth of vegetation. Catena 2014, 121, 195-203. [CrossRef]

28. Kiersnowska, A.; Stępień, S. Research the effect of temperature changes on strain and strength of woven geotextile. Przeglad Wlokienniczy 2014, 68, 25-29.

29. Hejduk, S.; Baker, S.W.; Spring, C.A. Evaluation of the effects of incorporation rate and depth of water-retentive amendment materials in sports turf constructions. Acta Agric. Scand. B Soil Plant Sci. 2012, 62, 155-164. [CrossRef]

30. Consoli, S.; Stagno, F.; Vanella, D.; Boaga, J.; Cassiani, G.; Roccuzzo, G. Partial root-zone drying irrigation in orange orchards: Effects on water use and crop production characteristics. Eur. J. Agron. 2017, 82, 190-202. [CrossRef]

31. Parvizi, H.; Sepaskhah, A.R.; Ahmadi, S.H. Physiological and growth responses of pomegranate tree (Punica granatum (L.) cv. Rabab) under partial root zone drying and deficit irrigation regimes. Agric. Water Manag. 2016, 163, 146-158. [CrossRef]

32. Nakhli, S.A.A.; Delkash, M.; Bakhshayesh, B.E.; Kazemian, H. Application of Zeolites for Sustainable Agriculture: A Review on Water and Nutrient Retention. Water Air Soil Pollut. 2017, 228, 34. [CrossRef]

33. Zhang, J.P.; Liu, R.F.; Li, A.; Wang, A.Q. Preparation, swelling behaviors and application of polyacrylamide/attapulgite superabsorbent composites. Polym. Adv. Technol. 2006, 17, 12-19. [CrossRef]

34. Ma, G.F.; Yang, Q.; Ran, F.T.; Dong, Z.B.; Lei, Z.Q. High performance and low cost composite superabsorbent based on polyaspartic acid and palygorskite clay. Appl. Clay Sci. 2015, 118, 21-28. [CrossRef]

35. Mumpton, F.A. La roca magica: Uses of natural zeolites in agriculture and industry. Proc. Natl. Acad. Sci. USA 1999, 96, 3463-3470. [CrossRef] [PubMed]

36. Basak, B.B.; Pal, S.; Datta, S.C. Use of modified clays for retention and supply of water and nutrients. Curr. Sci. 2012, 102, 1272-1278.

37. Zhang, Z.Z.; Wang, B.T. Preparation and water retention properties of clay-based sand-fixing and grass-planting materials. J. Wuhan Univ. Technol. 2013, 28, 325-328. [CrossRef]

38. Bulluck, L.R.; Brosius, M.; Evanylo, G.K.; Ristaino, J.B. Organic and synthetic fertility amendments influence soil microbial, physical and chemical properties on organic and conventional farms. Appl. Soil Ecol. 2002, 19, 147-160. [CrossRef]

39. Pinon-Villarreal, A.R.; Bawazir, A.S.; Shukla, M.K.; Samani, Z.A.; King, J.P. Modeling Capillary Rise in Clinoptilolite Zeolite and Riparian Soils to Sustain Vegetation in Water-Scarce Areas. J. Irrig. Drain. Eng. 2017, 143, 12. [CrossRef]

40. Thangarajan, R.; Bolan, N.S.; Tian, G.L.; Naidu, R.; Kunhikrishnan, A. Role of organic amendment application on greenhouse gas emission from soil. Sci. Total Environ. 2013, 465, 72-96. [CrossRef]

41. Wilske, B.; Bai, M.; Lindenstruth, B.; Bach, M.; Rezaie, Z.; Frede, H.G.; Breuer, L. Biodegradability of a polyacrylate superabsorbent in agricultural soil. Environ. Sci. Pollut. Res. 2014, 21, 9453-9460. [CrossRef]

42. Kono, H.; Fujita, S. Biodegradable superabsorbent hydrogels derived from cellulose by esterification crosslinking with 1,2,3,4-butanetetracarboxylic dianhydride. Carbohydr. Polym. 2012, 87, 2582-2588. [CrossRef]

43. Sarkar, S.; Datta, S.C.; Biswas, D.R. Effect of Fertilizer Loaded Nanoclay/Superabsorbent Polymer Composites on Nitrogen and Phosphorus Release in Soil. Proc. Indian Natl. Sci. Acad. Part B Biol. Sci. 2015, 85, 415-421. [CrossRef]

44. Stahl, J.D.; Cameron, M.D.; Haselbach, J.; Aust, S.D. Biodegradation of superabsorbent polymers in soil. Environ. Sci. Pollut. Res. 2000, 7, 83-88. [CrossRef] 
45. Rudzinski, W.E.; Dave, A.M.; Vaishanav, U.H.; Kumbar, S.G.; Kulkarni, A.R.; Aminabhavi, T.M. Hydrogels as controlled release devices in agriculture. Des. Monomers Polym. 2002, 5, 39-65. [CrossRef]

46. Zohuriaan-Mehr, M.J.; Omidian, H.; Doroudiani, S.; Kabiri, K. Advances in non-hygienic applications of superabsorbent hydrogel materials. J. Mater. Sci. 2010, 45, 5711-5735. [CrossRef]

47. Guilherme, M.R.; Aouada, F.A.; Fajardo, A.R.; Martins, A.F.; Paulino, A.T.; Davi, M.F.T.; Rubira, A.F.; Muniz, E.C. Superabsorbent hydrogels based on polysaccharides for application in agriculture as soil conditioner and nutrient carrier: A review. Eur. Polym. J. 2015, 72, 365-385. [CrossRef]

48. Yang, L.X.; Yang, Y.; Chen, Z.; Guo, C.X.; Li, S.C. Influence of super absorbent polymer on soil water retention, seed germination and plant survivals for rocky slopes eco-engineering. Ecol. Eng. 2014, 62, 27-32. [CrossRef]

49. Bakass, M.; Mokhlisse, A.; Lallemant, M. Absorption and desorption of liquid water by a superabsorbent polymer: Effect of polymer in the drying of the soil and the quality of certain plants. J. Appl. Polym. Sci. 2002, 83, 234-243. [CrossRef]

50. Laftah, W.A.; Hashim, S.; Ibrahim, A.N. Polymer Hydrogels: A Review. Polym. Plast. Technol. Eng. 2011, 50, 1475-1486. [CrossRef]

51. Narjary, B.; Aggarwal, P.; Singh, A.; Chakraborty, D.; Singh, R. Water availability in different soils in relation to hydrogel application. Geoderma 2012, 187, 94-101. [CrossRef]

52. Banedjschafie, S.; Durner, W. Water retention properties of a sandy soil with superabsorbent polymers as affected by aging and water quality. J. Plant Nutr. Soil Sci. 2015, 178, 798-806. [CrossRef]

53. Montesano, F.F.; Parente, A.; Santamaria, P.; Sannino, A.; Serio, F. Biodegradable Superabsorbent Hydrogel IncreasesWater Retention Properties of Growing Media and Plant Growth. Effic. Irrig. Manag. Eff. Urban Rural Landsc. 2015, 4, 451-458. [CrossRef]

54. Demitri, C.; Scalera, F.; Madaghiele, M.; Sannino, A.; Maffezzoli, A. Potential of Cellulose-Based Superabsorbent Hydrogels as Water Reservoir in Agriculture. Int. J. Polym. Sci. 2013, 2013. [CrossRef]

55. Chirino, E.; Vilagrosa, A.; Vallejo, V.R. Using hydrogel and clay to improve the water status of seedlings for dryland restoration. Plant Soil 2011, 344, 99-110. [CrossRef]

56. Magalhaes, A.S.G.; Neto, M.P.A.; Bezerra, M.N.; Feitosa, J.P.A. Superabsorbent Hydrogel Composite with Minerals Aimed at Water Sustainability. J. Braz. Chem. Soc. 2013, 24, 304-313. [CrossRef]

57. Koudela, M.; Hnilicka, F.; Svozilova, L.; Martinkova, J. Cauliflower qualities in two irrigation levels with the using of hydrophilic agent. Hortic. Sci. 2011, 38, 81-85. [CrossRef]

58. Huttermann, A.; Orikiriza, L.J.B.; Agaba, H. Application of Superabsorbent Polymers for Improving the Ecological Chemistry of Degraded or Polluted Lands. Clean Soil Air Water 2009, 37, 517-526. [CrossRef]

59. Kirkham, M.B. Principles of Soil and Plant Water Relations; Elsevier: Amsterdam, The Netherlands, 2005; pp. 1-500.

60. Han, Y.G.; Yang, P.L.; Luo, Y.P.; Ren, S.M.; Zhang, L.X.; Xu, L. Porosity change model for watered super absorbent polymer-treated soil. Environ. Earth Sci. 2010, 61, 1197-1205. [CrossRef]

61. Lejcus, K.; Spitalniak, M.; Dabrowska, J. Swelling Behaviour of Superabsorbent Polymers for Soil Amendment under Different Loads. Polymers 2018, 10, 271. [CrossRef]

62. Whalley, W.R.; Ober, E.S.; Jenkins, M. Measurement of the matric potential of soil water in the rhizosphere. J. Exp. Bot. 2013, 64, 3951-3963. [CrossRef] [PubMed]

63. Or, D.; Tuller, M.; Wraith, J.M. Encyclopedia of Soils in the Environment, Water Potential; Hillel, D., Ed.; Elsevier: Amsterdam, The Netherlands, 2005.

64. Song, Y.S. Suction stress in unsaturated sand at different relative densities. Eng. Geol. 2014, 176, 1-10. [CrossRef]

65. Chapin, F.S. Integrated Responses of Plants to Stress. Bioscience 1991, 41, 29-36. [CrossRef]

66. Eneji, A.E.; Islam, R.; An, P.; Amalu, U.C. Nitrate retention and physiological adjustment of maize to soil amendment with superabsorbent polymers. J. Clean. Prod. 2013, 52, 474-480. [CrossRef]

67. Lipiec, J.; Doussan, C.; Nosalewicz, A.; Kondracka, K. Effect of drought and heat stresses on plant growth and yield: A review. Int. Agrophysics 2013, 27, 463-477. [CrossRef]

68. Bartlett, M.K.; Klein, T.; Jansen, S.; Choat, B.; Sack, L. The correlations and sequence of plant stomatal, hydraulic, and wilting responses to drought. Proc. Natl. Acad. Sci. USA 2016, 113, 13098-13103. [CrossRef] [PubMed]

69. Sharp, R.E. Root growth maintenance during water deficits: Physiology to functional genomics. J. Exp. Bot. 2004, 55, 2343-2351. [CrossRef] 
70. Lejcus, K.; Dabrowska, J.; Grzybowska-Pietras, J.; Garlikowski, D.; Lejcus, I.; Pawlowski, A.; Spitalniak, M. Optimisation of Operational Parameters for Nonwoven Sheaths of Water Absorbing Geocomposites in Unsaturated Soil Conditions. Fibres Text. East. Eur. 2016, 24, 110-116. [CrossRef]

71. Bai, W.B.; Song, J.Q.; Zhang, H.Z. Repeated water absorbency of super-absorbent polymers in agricultural field applications: A simulation study. Acta Agric. Scand. B Soil Plant Sci. 2013, 63, 433-441. [CrossRef]

72. Lejcus, K.; Dabrowska, J.; Garlikowski, D.; Spitalniak, M. The application of water-absorbing geocomposites to support plant growth on slopes. Geosynth. Int. 2015, 22, 452-456. [CrossRef]

73. Lejcus, K.; Garlikowski, D.; Orzeszyna, H.; Pawlowski, A. Geocomposite with superabsorbent in landfill recultivation and slope protection. In Proceedings of the International Workshop on Management of Pollutant Emission from Landfills and Sludge, Kazimierz Dolny, Poland, 16-19 September 2006; pp. 151-157.

74. Śpitalniak, M. Wykorzystanie geokompozytów sorbujących wodę do ochrony skarp budowli ziemnych przed erozją. Inżynieria Morska i Geotechnika 2016, 3, 161-166.

75. Orzeszyna, H.; Garlikowski, D.; Pawłowski, A. Using of geocomposite with superabsorbent synthetic polymers as water retention element in vegetative layers. Int. Agrophysics 2006, 20, 201-206.

76. Wroblewska, K.; Debicz, R.; Babelewski, P. The Influence of Water Sorbing Geocomposite and Pine Bark Mulching on Growth and Flowering of some Perennial Species. Acta Sci. Pol. Hortorum Cultus 2012, 11, 203-216.

77. Babelewski, P.; Pancerz, M.; Debicz, R. The Influence of Geocomposites on the Biomass Production, the Nutritional Status of Plants and the Substrate Characteristics in the Container Nursery Production of Rosa cv. White Meidiland and Berberis Thunbergii cv. Green Carpet. J. Elementol. 2017, 22, 1095-1106. [CrossRef]

78. Kordas, L.; Kuc, P.; Lejcus, K. Biological Stabilisation of Tailing Pond Coasts with Use of Mineral and Organic Substances and Water-Absorbing Geocomposites. Pol. J. Environ. Stud. 2018, 27, 2089-2095. [CrossRef]

79. Bekier, J.; Bińczycki, T.; Bogacz, A.; Bojko, O.; Cuske, M.; Ćwielagg-Piasecka, I.; Dębicka, M.; Gałka, B.; Gersztyn, L.; Glina, B.; et al. Soils of Lower Silesia: Origins, diversity and protection [Gleby Dolnego Ślaska: Geneza, różnorodność i ochrona]; Kabała, C., Ed.; Uniwersytet Przyrodniczy we Wrocławiu Instytut Nauk o Glebie i Ochrony Środowiska: Wrocław, Poland, 2015.

80. FAO. World Reference Base for Soil Resources 2014. International soil classification system for naming soils and creating legends for soil maps. World Soil Resour. Rep. 2015, 106, 1-203.

81. Floerger SNF. Technical Data Sheet of Aquasorb. France, pp. 1-6. Available online: https://snf.com.au/ downloads/Aquasorb_E.pdf (accessed on 7 January 2019).

82. Erdem, T.; Arin, L.; Erdem, Y.; Polat, S.; Deveci, M.; Okursoy, H.; Gultas, H.T. Yield and quality response of drip irrigated broccoli (Brassica oleracea L. var. italica) under different irrigation regimes, nitrogen applications and cultivation periods. Agric. Water Manag. 2010, 97, 681-688. [CrossRef]

83. Corral, F.J.C.; Castano, S.B.; Fernandez, M.D.F.; Garcia, M.R.G.; Hernandez, J.C.L. Lysimetry methods for monitoring soil solution electrical conductivity and nutrient concentration in greenhouse tomato crops. Agric. Water Manag. 2016, 178, 171-179. [CrossRef]

84. Ishimwe, E.; Garner, C.D.; Coffman, R.A. Full-Scale Hydro-Mechanical Properties of Vertical Flow Bed Treatment Soils. Geotech. Geol. Eng. 2018, 36, 2735-2748. [CrossRef]

85. Munoz-Carpena, R.; Dukes, M.D.; Li, Y.C.C.; Klassen, W. Field comparison of tensiometer and granular matrix sensor automatic drip irrigation on tomato. Horttechnology 2005, 15, 584-590. [CrossRef]

86. Janik, G.; Dawid, M.; Walczak, A.; Slowinska-Osypiuk, J.; Skierucha, W.; Wilczek, A.; Daniel, A. Application of the TDR technique for the detection of changes in the internal structure of an earthen flood levee. J. Geophys. Eng. 2017, 14, 292-302. [CrossRef]

87. Malicki, M.A.; Skierucha, W.M. A Manually Controlled TDR Soil-Moisture Meter Operating with 300-PS Rise-Time Needle Pulse. Irrig. Sci. 1989, 10, 153-163. [CrossRef]

88. Skierucha, W. Accuracy of soil moisture measurement by tdr technique. Int. Agrophysics 2000, 14, 427-430.

89. Skierucha, W.; Wilczek, A.; Szyplowska, A.; Slawinski, C.; Lamorski, K. A TDR-Based Soil Moisture Monitoring System with Simultaneous Measurement of Soil Temperature and Electrical Conductivity. Sensors 2012, 12, 13545-13566. [CrossRef] [PubMed]

90. Skierucha, W.; Wilczek, A.; Alokhina, O. Calibration of a TDR probe for low soil water content measurements. Sens. Actuators A Phys. 2008, 147, 544-552. [CrossRef] 
91. Nicholson, R.V.; Gillham, R.W.; Cherry, J.A.; Reardon, E.J. Reduction of Acid Generation in Mine Tailings Through the Use of Moisture-Retaining Cover Layers as Oxygen Barriers. Can. Geotech. J. 1989, 26, 1-8. [CrossRef]

92. Akindunni, F.F.; Gillham, R.W.; Nicholson, R.V. Numerical Simulations to Investigate Moisture-Retention Characteristics in the Design of Oxygen-Limiting Covers for Reactive Mine Tailings. Can. Geotech. J. 1991, 28, 446-451. [CrossRef]

93. Park, K.D.; Fleming, I.R. Evaluation of a geosynthetic capillary barrier. Geotext. Geomembr. 2006, $24,64-71$. [CrossRef]

94. Bouazza, A.; Zornberg, J.; McCartney, J.S.; Singh, R.M. Unsaturated geotechnics applied to geoenvironmental engineering problems involving geosynthetics. Eng. Geol. 2013, 165, 143-153. [CrossRef]

95. McCartney, J.S.; Zornberg, J.G. Effect of Wet-Dry Cycles on Capillary Break Formation in Geosynthetic Drainage Layers. In Proceedings of the Geosynthetics 2007 Conference, Washington, DC, USA, 16-19 January 2007; pp. 1-10.

96. Iryo, T.; Rowe, R.K. On the hydraulic behavior of unsaturated nonwoven geotextiles. Geotext. Geomembr. 2003, 21, 381-404. [CrossRef]

97. Iryo, T.; Rowe, R.K. Hydraulic behaviour of soil-geocomposite layers in slopes. Geosynth. Int. 2005, 12, 145-155. [CrossRef]

98. Miszkowska, A.; Lenart, S.; Koda, E. Changes of Permeability of Nonwoven Geotextiles due to Clogging and Cyclic Water Flow in Laboratory Conditions. Water 2017, 9, 660. [CrossRef]

99. Krisdani, H.; Rahardjo, H.; Leong, E.C. Application of geosynthetic material in capillary barriers for slope stabilisation. Geosynth. Int. 2010, 17, 323-331. [CrossRef]

100. Li, X.P.; Chang, S.X.; Salifu, K.F. Soil texture and layering effects on water and salt dynamics in the presence of a water table: A review. Environ. Rev. 2014, 22, 41-50. [CrossRef]

101. Lehmann, P.; Assouline, S.; Or, D. Characteristic lengths affecting evaporative drying of porous media. Phys. Rev. E 2008, 77, 16. [CrossRef] [PubMed]

102. Steenhuis, T.S.; Hunt, A.G.; Parlange, J.Y.; Ewing, R.P. Assessment of the application of percolation theory to a water repellent soil. Aust. J. Soil Res. 2005, 43, 357-360. [CrossRef]

103. Shokri, N.; Salvucci, G.D. Evaporation from Porous Media in the Presence of a Water Table. Vadose Zone J. 2011, 10, 1309-1318. [CrossRef]

104. Lejcuś, K.; Dabrowska, J.; Garlikowski, D.; Kordas, L. Water loss from soil and water absorbing geocomposite. IPCBEE 2015, 84, 123-127.

105. Wróblewska, K.; Chohura, P.; Dębicz, R.; Lejcuś, K.; Dąbrowska, J. Water Absorbing Geocomposite: A Novel Method Improving Water and Fertilizer Efficiency in Brunnera macrophylla Cultivation. Part I. Plant Growth. Acta Sci. Pol. Hortorum Cultus 2018, 17, 49-56. [CrossRef] 